\title{
Host Range of Streptomycete Strains Causing Common Scab
}

Claudia Goyer and Carole Beaulieu, Groupe de recherche en Biologie des Actinomycètes, Département de Biologie, Université de Sherbrooke, Sherbrooke, Québec, Canada J1K 2R1

\begin{abstract}
Goyer, C., and Beaulieu, C. 1997. Host range of streptomycete strains causing common scab. Plant Dis. 81:901-904.

Ten Streptomyces isolates from common scab lesions on carrots (Daucus carota) were characterized. Morphological and physiological characterization of the carrot isolates established that they were closely related to $S$. scabies. DNA-DNA hybridization studies were carried out between DNA from the carrot isolates and DNA from two potato strains belonging to the two genetic clusters of $S$. scabies. Most of the carrot isolates exhibited a high level of DNA relatedness (average of 90\%) to strain EF-54, which belongs to genetic cluster 1 of S. scabies. Three carrot isolates could not be included in either $S$. scabies genetic cluster 1 or 2 . The pathogenicity of six S. scabies isolates from potato or carrot, two isolates of $S$. caviscabies, and one isolate of S. acidiscabies was determined on potato, carrot, radish, beet, turnip, and parsnip. All $S$. scabies isolates were pathogenic on carrot and radish, but pathogenicity on beet, parsnip, turnip, and potato was variable. Even though $S$. acidiscabies and S. caviscabies until now have been isolated only from potato, we demonstrated that isolates of these species also could infect other crops, such as radish, carrot, parsnip, and turnip.
\end{abstract}

Common scab is found in all potato-growing areas of North America and Europe (17). Characteristic symptoms of common scab of potato (Solanum tuberosum L.) are shallow, raised, or deep corky lesions on tubers (17). Common scab also is found on other crops, such as beet (Beta vulgaris L.), parsnip (Pastinaca sativa L.), and radish (Raphanus sativus L.) $(12,15,23,28)$. Typical symptoms of common scab also have been observed on carrot (Daucus carota L.) $(10,14)$.

Even though several Streptomyces species induce common scab, $S$. scabies is now considered the principal causal agent of the disease on potato (24). The confusion regarding the taxonomic identity of common scab-inducing organisms, resulting from the fact that $S$. scabies was considered for several years to be species incertae sedis, has been largely clarified since Lambert and Loria's (19) paper in which they redefined the species. S. scabies is characterized by smooth gray spores borne in spiral chains; production of melanin; utilization of L-arabinose, D-fructose, D-glucose, D-mannitol, rhamnose, sucrose, D-xylose, and raffinose; sensitivity to streptomycin; and no growth at $\mathrm{pH}$ 4.5. Most pathogenic strains isolated from potato lesions in eastern Canada and the United States belong to $S$. scabies $(7,19)$.

Corresponding author: C. Beaulieu

E-mail: c.beauli@courrier.usherb.ca

Accepted for publication 17 May 1997.

Publication no. D-1997-0620-02R

(C) 1997 The American Phytopathological Society
Healy and Lambert (11) demonstrated that pathogenic potato strains exhibiting phenotypic characteristics of $S$. scabies were genetically diverse. In DNA-DNA hybridization studies, levels of DNA relatedness between $S$. scabies strains varied considerably. Although most S. scabies strains isolated from the United States had at least $70 \%$ DNA relatedness to the neotype strain, some strains exhibited a level of DNA relatedness as low as $20 \%$. In eastern Canada, potato strains phenotypically related to $S$. scabies were divided into two genetic clusters. Levels of DNA relatedness between strains from the two genetic clusters were low (average of 44\%) (25). The neotype strain of S. scabies (19) was included in genetic cluster 2 and showed $72 \%$ DNA relatedness to strain EF-35 isolated from plants in Québec.

The taxonomic identity of streptomycetes that induce common scab on carrot and crops other than potato has received little attention. Jones (15) demonstrated that a pathogenic potato isolate could induce common scab lesions on beet, radish, carrot, and parsnip. More recently, Janse (14) isolated seven pathogenic Streptomyces isolates from common scab lesions on carrots in the Netherlands. These isolates all produced melanin pigment and smooth gray spores borne in spiral chains. All isolates utilized L-arabinose, D-mannitol, D-fructose, D-raffinose, sucrose, and $\mathrm{D}$-xylose as the sole carbon source. Based on these characteristics, the carrot isolates should be classified as $S$. scabies. Carrot scab also was reported recently in Michigan by Hanson and Lacy (10) who isolated pathogenic Streptomyces from carrot lesions. The pathogenic isolate exhibited char- acteristics typical of $S$. scabies, except the spores were echinulate rather than smooth.

In 1993, severe cases of common scab on carrot were observed on Orleans Island, Québec. The purpose of this work was (i) to characterize actinomycetes from scab lesions on carrot, (ii) to determine the DNA relatedness between the pathogenic isolates from carrots and potatoes, and (iii) to compare the host range of pathogenic actinomycetes isolated from potato or carrot.

\section{MATERIALS AND METHODS}

Isolation of actinomycetes associated with common scab lesions on carrot. Infected carrots, cv. Avenger, were obtained from Orleans Island, Québec, where a severe outbreak of common scab was recorded in 1993. Actinomycetes were isolated from carrot lesions, following a modified protocol of Faucher et al. (7). Infected carrot pieces were soaked in a mixture of phenol and sterile water (1:140) for $10 \mathrm{~min}$ (21) and rinsed twice with sterile water for $15 \mathrm{~min}$. About $5 \mathrm{~mm}^{3}$ of carrot tissue was aseptically removed from immediately below a lesion and transferred to a tube containing $10 \mathrm{ml}$ of sterile tap water. The tube was placed in a water bath at $55^{\circ} \mathrm{C}$ for $30 \mathrm{~min}$. The carrot pieces were plated on water agar $(1.2 \%)$ containing $50 \mathrm{mg}$ of nystatin, $5 \mathrm{mg}$ of polymixin B sulfate, $1 \mathrm{mg}$ of sodium penicillin $\mathrm{G}$, and $50 \mathrm{mg}$ of cycloheximide per liter (3). Plates were incubated at $30^{\circ} \mathrm{C}$ for 10 days. Spores on or around the carrot tissues were picked up and streaked on yeast malt extract (YME) agar media (26) supplemented with the same antibiotics. Isolates were streaked three times on YME agar to ensure purity of cultures and were maintained on YME agar.

Physiological and morphological characterization. All minimal media were composed of $2.64 \mathrm{~g}$ of $\left(\mathrm{NH}_{4}\right)_{2} \mathrm{SO}_{4}, 2.38 \mathrm{~g}$ of $\mathrm{KH}_{2} \mathrm{PO}_{4}, 5.65 \mathrm{~g}$ of $\mathrm{K}_{2} \mathrm{HPO}_{4} \cdot 3 \mathrm{H}_{2} \mathrm{O}, 1.00 \mathrm{~g}$ of $\mathrm{MgSO}_{4} \cdot 7 \mathrm{H}_{2} \mathrm{O}, 6.4 \mathrm{mg}$ of $\mathrm{CuSO}_{4} \cdot 5 \mathrm{H}_{2} \mathrm{O}$, $1.1 \mathrm{mg}$ of $\mathrm{FeSO}_{4} \cdot 7 \mathrm{H}_{2} \mathrm{O}, 7.9 \mathrm{mg}$ of $\mathrm{MnCl}_{2} \cdot \mathrm{H}_{2} \mathrm{O}$, and $1.5 \mathrm{~g}$ of $\mathrm{ZnSO}_{4} \cdot 7 \mathrm{H}_{2} \mathrm{O}$ per liter (19). Carbon source utilization was tested on solid minimal medium containing $2 \%$ (wt/vol) of various sugars, each as the sole carbon source. Peptone yeast extract iron (PYI) was utilized to test melanin production (19). The ability of the isolates to grow in the presence of streptomycin $(20 \mathrm{mg} / \mathrm{liter})$ was tested as proposed by Faucher et al. (7). Spores were examined by scanning electron microscopy as previously described (5). The colors of the colonies and spore mass were described after 
10 days of growth at $30^{\circ} \mathrm{C}$ on YME agar. All morphological and physiological tests were repeated three times.

Pathogenicity tests. Pathogenicity tests were carried out according to Faucher et al.
(7). To prepare the inoculum, Streptomyces isolates (S. acidiscabies strain ATCC 49003 [20], S. caviscabies strains EF-87 and EF98 [8], and S. scabies strains EF-35, EF54, C1, C2, C3, C4, C5, C6, C7, C8, C9,

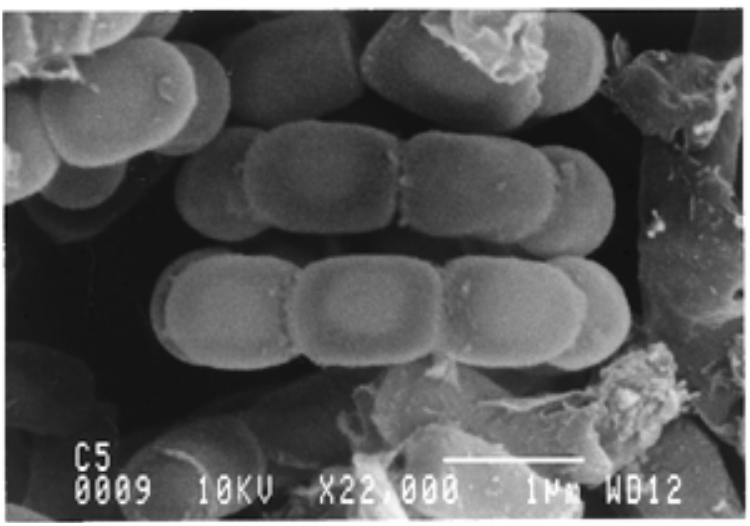

Fig. 1. Scanning electron micrograph of a spiral spore chain of Streptomyces scabies strain C5. Bar $=1 \mu \mathrm{m}$.

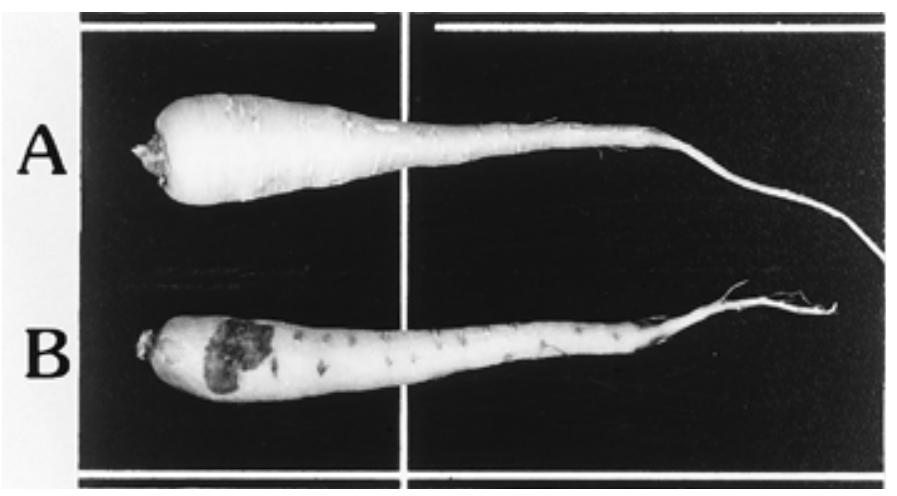

Fig. 2. Carrot roots grown in soil (A) noninfested and (B) infested with Streptomyces scabies isolate C9. Carrot inoculated with C9 (B) shows typical common scab symptoms.

and $\mathrm{C} 10)$ were incubated for 2 weeks at $30^{\circ} \mathrm{C}$ in $50-\mathrm{ml}$ tubes containing vermiculite saturated with a modified Say solution composed of $20 \mathrm{~g}$ of sucrose, $1.2 \mathrm{~g}$ of Lasparagine, $0.6 \mathrm{~g}$ of $\mathrm{K}_{2} \mathrm{HPO}_{4}$, and $10 \mathrm{~g}$ of yeast extract per liter of water (17). Seeds of D. carota cv. Imperator 408 (carrot), $B$. vulgaris cv. Early Wonder (beet), $P$. sativa cv. Andover (parsnip), Brassica napus L. var. rapifera $\mathrm{cv}$. Laurentian (turnip), and $R$. sativus cv. Scarlet Globe (radish), as well as tubers of $S$. tuberosum cvs. Conestoga and Yukon Gold (potato), were soaked twice in a $0.5 \%$ sodium hypochlorite solution for $15 \mathrm{~min}$ and rinsed in sterile water for 15 min. Potato tubers or seeds were planted in 27-cm-diameter pots containing sterile sand mixed with inoculum. For each plant species analyzed, pots were arranged in a growth chamber in a complete, randomized block with three replicates. Uninfested controls were included in the tests. Plants were grown at $25^{\circ} \mathrm{C}$ at $90 \%$ relative humidity with a 16-h photoperiod. Vegetables were harvested after 3 to 4 months, and at least three tubers or roots from each replicate were examined for scab symptoms.

DNA-DNA hybridization. Total DNA from Streptomyces isolates was isolated according to Hopwood et al. (13). The DNA reassociation experiments were performed according to Stall et al. (27) as modified by Paradis et al. (25). Briefly, DNA of EF-54, a $S$. scabies strain belonging to genetic cluster 1, and DNA of EF-35, a S. scabies strain belonging to genetic cluster 2 , were labeled by incorporating tritiated dCTP into sheared genomic DNA by the random primer method. Sheared DNA of the 10 carrot isolates was hybridized with labeled DNA of EF-35 and EF-54. DNA reassociation was carried out for $24 \mathrm{~h}$ at $64^{\circ} \mathrm{C}$. After reassociation, 300 units of nuclease $\mathrm{S} 1$ was added, and the tubes were incubated for $1 \mathrm{~h}$ at $50^{\circ} \mathrm{C}$. DNA was incorporated on Whatman (Maidstone, England)

Table 1. Pathogenic behavior of streptomycetes on different plant species

\begin{tabular}{|c|c|c|c|c|c|c|c|}
\hline \multirow[b]{2}{*}{$\begin{array}{l}\text { Streptomyces } \\
\text { strain }\end{array}$} & \multicolumn{7}{|c|}{ Strain pathogenicity } \\
\hline & $\begin{array}{c}\text { Beet cv. } \\
\text { Early Wonder }\end{array}$ & $\begin{array}{c}\text { Carrot cv. } \\
\text { Imperator } 408\end{array}$ & $\begin{array}{l}\text { Parsnip cv. } \\
\text { Andover }\end{array}$ & $\begin{array}{c}\text { Radish cv. } \\
\text { Scarlet Globe }\end{array}$ & $\begin{array}{l}\text { Turnip cv. } \\
\text { Laurentian }\end{array}$ & $\begin{array}{l}\text { Potato cv. } \\
\text { Conestoga }\end{array}$ & $\begin{array}{l}\text { Potato cv. } \\
\text { Yukon Gold }\end{array}$ \\
\hline \multicolumn{8}{|l|}{ S. acidiscabies } \\
\hline ATCC 49003 & - & - & - & +++ & +++ & +++ & $\mathrm{ND}^{\mathrm{b}}$ \\
\hline \multicolumn{8}{|l|}{ S. caviscabies } \\
\hline EF-87 & - & ++ & - & +++ & - & DPS $^{c}$ & ND \\
\hline EF-98 & - & - & ++ & ++ & - & DPS & ND \\
\hline \multicolumn{8}{|l|}{ S. scabies } \\
\hline \multicolumn{8}{|l|}{ Potato isolate } \\
\hline EF-35 & + & ++ & ++ & +++ & ++ & ++ & ND \\
\hline EF-54 & - & ++ & - & + & - & ++ & ND \\
\hline \multicolumn{8}{|l|}{ Carrot isolate } \\
\hline $\mathrm{C} 4$ & - & + & - & ++ & - & - & ++ \\
\hline $\mathrm{C} 5$ & - & + & - & + & - & - & - \\
\hline C6 & - & ++ & - & ++ & - & - & - \\
\hline C9 & - & ++ & - & + & - & - & +++ \\
\hline
\end{tabular}

$\mathrm{a}_{-=}$no symptoms; + = mild symptoms (scab lesions were found on 5 to $10 \%$ of the plant organ surface); $++=$ moderate symptoms (scab lesions were found on 10 to $30 \%$ of the plant organ surface); and +++ = severe symptoms (scab lesions were found on more than $30 \%$ of the plant organ surface.

${ }^{\mathrm{b}} \mathrm{ND}=$ not determined.

${ }^{\mathrm{c}}$ Isolates induce deep-pitted scab (DPS) on potato. 
GF/C glass-fiber filters. Radioactivity on the filters was recorded with a Beckman (Fullerton, CA) LS7000 scintillation counter. The hybridization values for pairs of strains were means of the values from two experiments; for each experiment, two hybridization reactions were performed.

\section{RESULTS}

Isolation and characterization of actinomycetes isolated from carrot scab lesions. Ten actinomycetes isolates from carrot lesions all exhibited the same morphological properties on YME agar: brown to tan colonies with gray spores borne in spiral chains. Spores were cylindrical, measured approximately $1.0 \mu \mathrm{m} \times 1.1 \mu \mathrm{m}$, and presented a smooth surface (Fig. 1). Melanoid pigment was synthesized on PYI medium. L-Arabinose, D-mannitol, D-fructose, D-glucose, I-inositol, D-raffinose, sucrose, and D-xylose were utilized as the sole carbon source by all isolates. Their growth was inhibited in the presence of streptomycin. These morphological and physiological characteristics are typical of $S$. scabies (19).

Pathogenicity tests. All 10 actinomycetes isolates from carrot lesions were pathogenic on carrot. Isolates $\mathrm{C} 2, \mathrm{C} 6, \mathrm{C} 7$, and C9 caused severe lesions on carrots (Fig. 2), whereas isolates $\mathrm{C} 1, \mathrm{C} 3, \mathrm{C} 4, \mathrm{C} 5, \mathrm{C} 8$, and C10 caused mild symptoms. Necrosis caused by isolates $\mathrm{C} 1, \mathrm{C} 3, \mathrm{C} 4, \mathrm{C} 5, \mathrm{C} 8$, and $\mathrm{C} 10$ arose mostly in the lateral root orifices. The pathogenicity of four carrot isolates
(C4, C5, C6, and C9) also were tested on other crops. All were pathogenic on radish but not on beet, parsnip, and turnip. Isolates $\mathrm{C} 5$ and $\mathrm{C} 6$ were not pathogenic on the two potato cultivars tested (Conestoga and Yukon Gold), whereas isolates C4 and C9 induced moderate to severe symptoms on cv. Yukon Gold but not on cv. Conestoga (Table 1).

The EF-35 isolate was the only isolate of $S$. scabies pathogenic on all crops tested. Potato isolate EF-54 induced common scab only on carrot and potato (Table 1).

Isolates of $S$. acidiscabies and $S$. caviscabies caused common scab on potato and radish but, none were pathogenic on beet. $S$. acidiscabies also induced lesions on turnip (Fig. 3A), whereas at least one isolate of $S$. caviscabies was pathogenic on parsnip (Fig. 3B) or carrot (Table 1).

Plants grown in noninfested soil remained symptomless, and Koch's postulates were successfully carried out for all infected plants.

DNA-DNA hybridization. In Eastern Canada, S. scabies strains from potato have been divided into two genetic clusters (25). Levels of DNA relatedness between carrot isolates $\mathrm{C} 1, \mathrm{C} 2, \mathrm{C} 3, \mathrm{C} 4, \mathrm{C} 8, \mathrm{C} 9$, and $\mathrm{C} 10$ and potato isolate EF-54 (genetic cluster 1) ranged from 67 to $100 \%$. These carrot isolates, thus, can be classified into S. scabies genetic cluster 1 . The level of DNA relatedness between strain EF-54 and carrot isolates C5, C6 and C7 was below $41 \%$ (Table 2). Levels of DNA relatedness be-

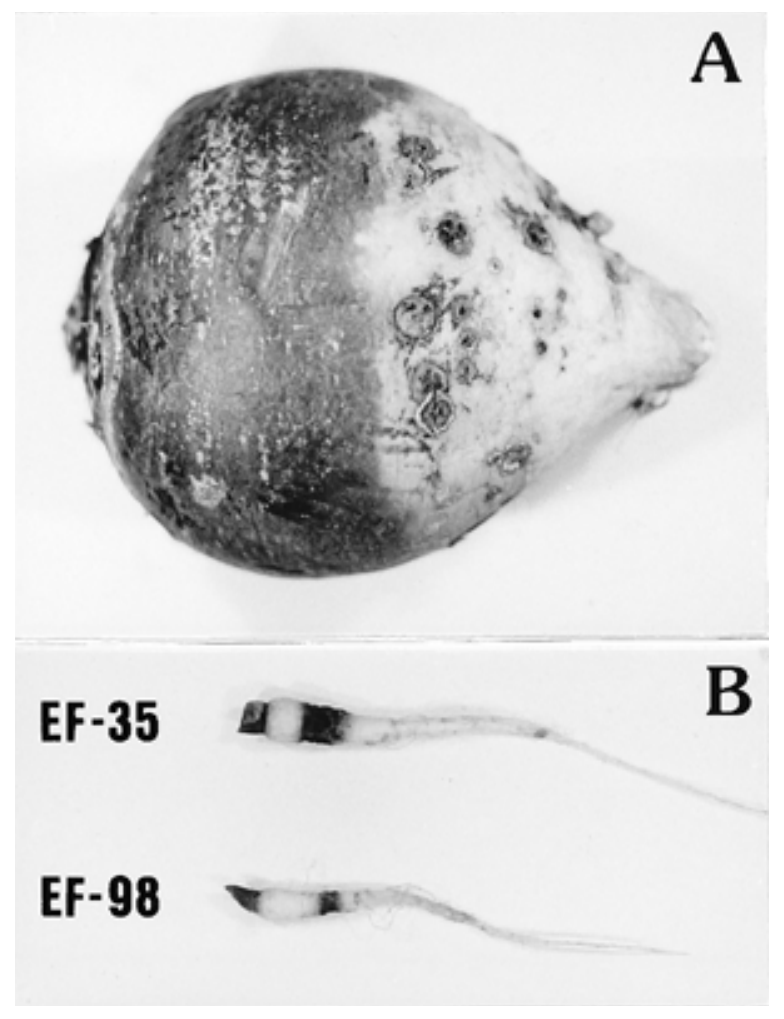

Fig. 3. Symptoms of common scab on (A) turnip cv. Laurentian infected with Streptomyces acidiscabies strain ATCC 49003 and (B) parsnip infected with S. scabies strain EF-35 and S. caviscabies strain EF-98.

tween DNA from EF-35 (genetic cluster 2) and DNA from all carrot isolates were low (between 0 and $43 \%$ ).

\section{DISCUSSION}

This paper presents the first extensive study of the host range of streptomycetes causing common scab, and we show that the pathogenicity of $S$. scabies, $S$. acidiscabies, and $S$. caviscabies strains is not limited to potato. Previous reports suggested that $S$. scabies and $S$. acidiscabies induced scab on several crops $(12,14,15$, $18,23,28)$, but this is the first report demonstrating that $S$. caviscabies can cause symptoms on crops other than potato. It also has been reported that $S$. scabies reduced seedling growth of many plant species (22); however, the effects of $S$. acidiscabies and $S$. caviscabies on seedlings still need to be studied.

S. caviscabies isolates were the only bacteria that induced deep-pitted scab on potato cv. Conestoga. However, symptoms caused by $S$. caviscabies on others crops could not be distinguished from those caused by $S$. scabies and $S$. acidiscabies (Fig. 3B).

This study confirms previous work by Jones (15), Janse (14), and Hanson and Lacy (10) who associated carrot scab with infection by Streptomyces. Symptoms observed on carrot were similar to those described by Janse (14). In addition, we establish that our carrot isolates are phenotypically related to S. scabies. Indeed, their physiological properties (sugar utilization, antibiotic resistance, and melanin production) as well as their morphological properties (colony color, mass spore color, morphology of spore chain, and spore surface) are typical of $S$. scabies. In contrast to the pathogenic carrot isolate tested by Hanson and Lacy (10), which produced echinulate spores, our carrot isolates bore smooth spores similar to those produced by potato strains of S. scabies. We, therefore, conclude that the pathogenic carrot isolates we obtained belong to the species $S$. scabies.

Table 2. Levels of DNA homology between carrot isolates and Streptomyces scabies strains EF54 (genetic cluster 1) and EF-35 (genetic cluster 2) from potato

\begin{tabular}{ccc}
\hline & \multicolumn{2}{c}{$\%$ Hybridization } \\
\cline { 2 - 3 } Isolate & Strain EF-54 & Strain EF-35 \\
\hline Potato & & \\
EF-35 & 54 & 100 \\
EF-54 & 100 & 50 \\
Carrot & & \\
C1 & 100 & 21 \\
C2 & 100 & 26 \\
C3 & 100 & 43 \\
C4 & 91 & 40 \\
C5 & 41 & 0 \\
C6 & 20 & 3 \\
C7 & 4 & 0 \\
C8 & 85 & 26 \\
C9 & 90 & 23 \\
C10 & 67 & 1 \\
\hline
\end{tabular}

Plant Disease / August 1997903 
This is not always the case. Pathogenic streptomycetes isolated from other crops such as sugar beet (28), radish (23), and potato $(4,6-8,20)$ sometimes present phenotypes considerably different from that of S. scabies.

Infected carrots were obtained from a field where no common scab had been observed for the last 15 years and where potatoes had not been grown during the same time period. Thus, it is improbable that the pathogenic population infecting carrot was selected for by cropping potato even though some carrot isolates were pathogenic on potato. Most carrot isolates $(\mathrm{C} 1$, $\mathrm{C} 2, \mathrm{C} 3, \mathrm{C} 4, \mathrm{C} 8, \mathrm{C} 9$, and $\mathrm{C} 10$ ) were placed in genetic cluster 1 of $S$. scabies based on their relatively high level of DNA relatedness (67 to $100 \%$ ) to strain EF-54 isolated from potato. Potato and carrot isolates belonging to genetic group 1 exhibited a similar host range. They were nonpathogenic on the beet, parsnip, and turnip cultivars tested, but they caused common scab on carrot, radish, and potato. The ability of $S$. scabies to cause disease also depends on the cultivar. For example, EF-54 and C4 were both pathogenic on potato, but only EF-54 induced common scab lesions on cv. Conestoga. The pathogenic behavior of isolates of other bacterial plant pathogens such as Erwinia and Xanthomonas $(1,2)$ also varies according to cultivar.

Three carrot isolates (C5, C6, and C7) could not be associated with genetic cluster 1 nor with genetic cluster 2 of $S$. scabies. This indicates that strains phenotypically related to $S$. scabies in Québec can be divided into at least three genetic clusters. Despite distinctive phenotypic traits (19), it would appear that $S$. scabies strains show more genetic diversity than a conventional species, as was also pointed out by Healy and Lambert (11). Moreover, this appears to be independent of the host plant, because genetic diversity has been reported within potato $(11,25)$ and sugar beet isolates (28), as well as carrot isolates (this study).

Although virulence mechanisms of pathogenic streptomycetes are still poorly understood; thaxtomins, a group of phytotoxins, appear to play an important role in pathogenicity. Indeed, King et al. (16) showed a positive correlation between thaxtomin production and pathogenicity. Goyer et al. (9) reported previously that the potato isolates used in the current study produced thaxtomin A. Carrot isolate C6 also produced thaxtomin in oatmeal medium (data not shown). A study comparing thaxtomin production by Streptomyces strains of different species and from different hosts is in progress.
During the last few years, there has been impressive progress made in identification and taxonomy of streptomycetes causing common scab, but the situation remains complex. Not only has it been demonstrated that several Streptomyces species, including $S$. scabies, are causal agents of the disease on potato $(8,19,20)$, evidence also is accumulating that $S$. scabies may not be a homogeneous species but rather a heterogeneous species composed of different genetic clusters.

\section{ACKNOWLEDGEMENTS}

This work was supported by a grant from the Natural Sciences and Engineering Research Council of Canada. C. Goyer gratefully acknowledges a scholarship from the Fonds pour la Formation des Chercheurs et l'Aide à la Recherche du Gouvernement du Québec. We thank B. Otrysko for a critical reading of the manuscript and P. Magny for work in microscopy. We also thank P. Coulombe for giving us carrot samples.

\section{LITERATURE CITED}

1. Allefs, J. J. M., Vandooijeweert, W., Dejong, E. R., Prummel, W., and Hoogendoorn, J. 1995. Factors affecting potato soft-rot resistance to pectinolytic Erwinia species in a tuber-slice assay. J. Phytopathol. 143:705-711.

2. Bouzar, H., Jones, J. B., Stall, R. E., Hodge, N. C., Minsavage, G. V., Benedict, A. A., and Alvarez, A. M. 1994. Physiological, chemical, serological, and pathogenic analyses of a worldwide collection of Xanthomonas campestris pv. vesicatoria strains. Phytopathology 84:663-671.

3. Davies, F. L., and William, S. T. 1970. Studies on the ecology of actinomycetes in soil. I. The occurrence and distribution of actinomycetes in a pine forest soil. Soil Biol. Biochem. 2:227-238

4. Doering-Saad, C., Kämpfer, P., Manulis, S., Kritzman, G., Schneider, J., ZakrzewskaCzerwinska, J., Schrempf, H., and Barash, I. 1992. Diversity among Streptomyces strains causing potato scab. Appl. Environ. Microbiol. 58:3932-3940.

5. Faucher, E., Otrysko, B., Paradis, E., Hodge, N. C., Stall, R. E., and Beaulieu, C. 1993. Characterization of streptomycetes causing russet scab in Québec. Plant Dis. 77:1217-1220.

6. Faucher, E., Paradis, E., Goyer, C., Hodge, N. C., Hogue, R., Stall, R. E., and Beaulieu, C. 1995. Characterization of streptomycetes causing deep-pitted scab of potato in Québec, Canada. Int. J. Syst. Bacteriol. 45:222-225.

7. Faucher, E., Savard, T., and Beaulieu, C. 1992. Characterization of actinomycetes isolated from common scab lesions on potato tubers. Can. J. Plant Pathol. 14:197-202.

8. Goyer, C., Faucher, E., and Beaulieu, C. 1996. Streptomyces caviscabies sp. nov., from deeppitted lesions in potatoes in Québec, Canada. Int. J. Syst. Bacteriol. 46:635-639.

9. Goyer, C., Otrysko, B., and Beaulieu, C. 1996. Taxonomic studies on streptomycetes causing potato common scab: A review. Can. J. Plant Pathol. 18:107-113.

10. Hanson, L. E., and Lacy, M. L. 1990. Carrot scab caused by Streptomyces spp. in Michigan. Plant Dis. 74:1037.

11. Healy, F. G., and Lambert, D. H. 1991. Relationships among Streptomyces spp. causing potato scab. Int. J. Syst. Bacteriol. 41:479482.

12. Hoffmann, H. 1991. Plant diseases caused by streptomycetes. Pages 2039-2042 in: The Prokaryotes: A Handbook on the Biology of Bacteria: Ecophysiology, Isolation, Identification and Applications. 2nd ed. A. Balows, H. G. Dworkin, W. Harder, and K.-H. Schleifer, eds. Springer-Verlag, New York.

13. Hopwood, D. A., Bibbs, M. J., Chater, K. F., Kieser, T., Bruton, C. J., Kieser, H. M., Lydiate, D. J., Smith, C. P., Ward, J. M., and Schrempf, H. 1985. Genetic manipulation of Streptomyces: A Laboratory Manual. The John Innes Foundation, Norwich, England.

14. Janse, J. D. 1988. A Streptomyces species identified as the cause of carrot scab. Neth. J. Plant Pathol. 94:303-306.

15. Jones, A. P. 1953. Parsnip canker. Nature (Lond.) 171:574.

16. King, R. R., Lawrence, C. H., and Calhoun, L. A. 1991. Correlation of phytotoxin production with pathogenicity of Streptomyces scabies isolates from scab infected potato tubers. Am. Potato J. 68:675-680.

17. Labruyère, R. E. 1971. Common Scab and Its Control in Seed Potato Crops. Centre for $\mathrm{Ag}$ ricultural Publishing and Documentation, Wageningen, Netherlands.

18. Lambert, D. H. 1991. First report of additional hosts for the acid scab pathogen Streptomyces acidiscabies. Plant Dis. 75:750.

19. Lambert, D. H., and Loria, R. 1989. Streptomyces scabies sp. nov; nom. rev. Int. J. Syst. Bacteriol. 39:387-392.

20. Lambert, D. H., and Loria, R. 1989. Streptomyces acidiscabies sp. nov. Int. J. Syst. Bacteriol. 39:393-396.

21. Lawrence, C. H. 1956. A method of isolating actinomycetes from scabby potato tissue and soil with minimal contamination. Can. J. Bot. 34:44-47.

22. Leiner, R. H., Fry, B. A., Carling, D. E., and Loria, R. 1996. Probable involvement of thaxtomin A in pathogenicity of Streptomyces scabies on seedlings. Phytopathology 86:709713 .

23. Levick, D. R., Evans, T. A., Stephens, C. T., and Lacy, M. L. 1985. Etiology of radish scab and its control through irrigation. Phytopathology 75:568-572.

24. Locci, R. 1994. Actinomycetes as plant pathogens. Eur. J. Plant. Pathol. 100:179-200.

25. Paradis, E., Goyer, C., Hodge, N. C., Hogue, R., Stall, R. E., and Beaulieu, C. 1994. Fatty acid and protein profiles of Streptomyces scabies strains isolated in eastern Canada. Int. J. Syst. Bacteriol. 44:561-564.

26. Pridham, T. G., Anderson, P., Foley, C., Lindenfelser, L. A., Hessetine, C. W., and Benedict, R. G. 1956-1957. A selection of media for maintenance and taxonomic study of streptomycetes. Antibiot. Annu. 1956-1957: 947-953.

27. Stall, R. E., Beaulieu, C., Egel, D., Hodge, N. C., Leite, R. P., Minsavage, G. V., Bouzar, H., Jones, J. B., Alvarez, A. M., and Benedict, A. A. 1994. Two genetically diverse groups of strains are included in Xanthomonas campestris pv. vesicatoria. Int. J. Syst. Bacteriol. 44: 47-52.

28. Tashiro, N., Miyashita, K., and Suzui, T. 1990. Taxonomic studies on the Streptomyces species isolated as causal organisms of potato common scab. Ann. Phytopathol. Soc. Jpn. 56: 73-82. 